\title{
Cupreines and cupreidines: an established class of bifunctional cinchona organocatalysts
}

\author{
Laura A. Bryant, Rossana Fanelli and Alexander J. A. Cobb*
}

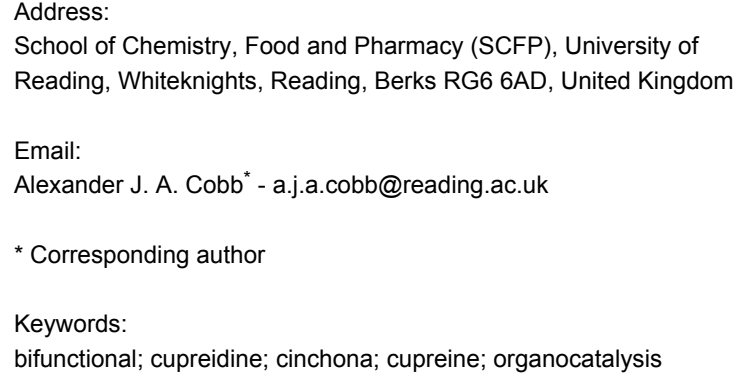

Beilstein J. Org. Chem. 2016, 12, 429-443.

doi:10.3762/bjoc. 12.46

Received: 27 November 2015

Accepted: 16 February 2016

Published: 07 March 2016

This article is part of the Thematic Series "Bifunctional catalysis".

Guest Editor: D. J. Dixon

(๑) 2016 Bryant et al; licensee Beilstein-Institut. License and terms: see end of document.

\begin{abstract}
Cinchona alkaloids with a free 6'-OH functionality are being increasingly used within asymmetric organocatalysis. This fascinating class of bifunctional catalyst offers a genuine alternative to the more commonly used thiourea systems and because of the different spacing between the functional groups, can control enantioselectivity where other organocatalysts have failed. In the main, this review covers the highlights from the last five years and attempts to show the diversity of reactions that these systems can control. It is hoped that chemists developing asymmetric methodologies will see the value in adding these easily accessible, but underused organocatalysts to their screens.
\end{abstract}

\section{Introduction}

The cinchona alkaloids, comprising quinine $(\mathbf{Q N})$, quinidine (QD), cinchonidine (CD), cinchonine (CN, Figure 1), and their derivatives have revolutionized asymmetric catalysis owing to their privileged structures. The functional groups within these catalysts are highly pre-organized [1,2] and can both coordinate to, and activate the components of a reaction in a well-defined manner, thus facilitating a stereocontrolled process. The ability to easily derivatise these catalyst systems in a bespoke fashion in order to optimize their stereoselective behaviour has seen their utility burgeon dramatically over the last decade. Of particular note is the use of these cinchona systems within bifunctional thiourea catalysis [3-12].
Cupreine (CPN) and cupreidine (CPD), the non-natural demethylated structures of quinine and quinidine, respectively, have also found extensive utility, but not to the same extent, which is surprising given the broad range of chemistries that they have been shown to facilitate, and which are the subject of this review.

Herein, we describe the highlights of CPN, CPD and their derivatives in asymmetric organocatalysis over the last five years or so $[13,14]$. The review is organized by reaction type, beginning with the Morita-Baylis-Hillman process - one of the first reactions to utilize 6 '- $\mathrm{OH}$-cinchona alkaloid derivatives in 
<smiles>[R]c1ccc2nccc([C@@H](O)[C@H]3CC4CCN3CC4C=C)c2c1</smiles>

quinine (QN)

cinchonidine (CD)

cupreine (CPN)

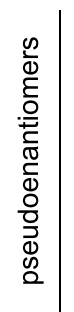

$\mathrm{R}=\mathrm{OMe}$

$\mathrm{R}=\mathrm{H}$

$\mathrm{R}=\mathrm{OH}$<smiles>[R]c1ccc2nccc([C@@H](O)C3C4CCN3CC4C=C)c2c1</smiles>

quinidine (QD)

cinchonine (CN) cupreidine (CPD)

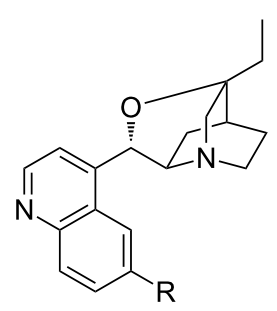

$\beta$-isoquinidine $(\boldsymbol{\beta}$-IQD) $\mathrm{R}=\mathrm{OMe}$

$\beta$-isocupreidine ( $\beta$-ICPD or $\beta$-ICD) $\mathrm{R}=\mathrm{OH}$

Figure 1: The structural diversity of the cinchona alkaloids, along with cupreine, cupreidine, $\beta$-isoquinidine and $\beta$-isocupreidine derivatives.

asymmetric organocatalysis. The focus will then turn to asymmetric 1,2-additions followed by conjugate additions, a cyclopropanation, (ep)oxidations, $\alpha$-functionalisation processes, cycloadditions, domino processes and finally miscellaneous reactions. We ultimately aim to demonstrate through this plethora of diverse processes, that the 6'-OH cinchona class of alkaloids are a dynamic and versatile type of organocatalyst that should be included in the screening libraries of chemists seeking to develop asymmetric methodologies.

\section{Review}

\section{Morita-Baylis-Hillman (MBH) and MBH- carbonate reactions}

The first reports of an asymmetric reaction catalyzed by a cinchona organocatalyst with a 6'-OH functionality came from Hatakeyama and co-workers in 1999 who demonstrated the use of $\boldsymbol{\beta}$-ICPD in an asymmetric Morita-Baylis-Hillman (MBH) reaction [15-18] what is essentially an asymmetric C3-substituted ammonium enolate reaction (Scheme 1) [19,20]. In this classic process, it was hypothesized that the 6'-OH group was critical in directing the incoming aldehyde electrophile (see Scheme 1 box).

Soon after, Shi and co-worker demonstrated the use of $\boldsymbol{\beta}$-ICPD in the reaction of imines $\mathbf{5}$ with methyl vinyl ketone (MVK, 6) using the same catalyst (Scheme 2) [21]. The same study investigated methylacrylate and acrylonitrile as the conjugated partner, but these were less successful. Shi proposed a similar reaction mechanism for this process, whereby the 6'-OH functionality is critical in the control of stereoselectivity.

In a more recent extension of this work, Shi, $\mathrm{Li}$ and co-workers partnered the isatin derived $N$-Boc ketimines 8 with MVK (6, Scheme 3 a) to obtain the corresponding adducts 9 with very<smiles>[R]C(=O)[CH-]C(=O)OC(C(F)(F)F)C(F)(F)F</smiles><smiles>[R]C1OC([R])C([R])OC(=O)C1=C</smiles>

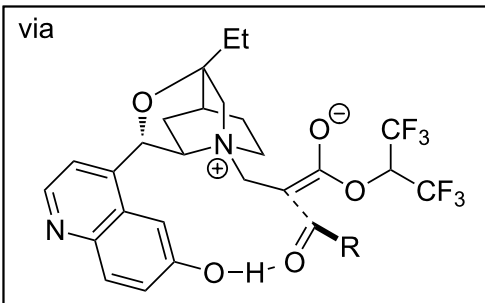




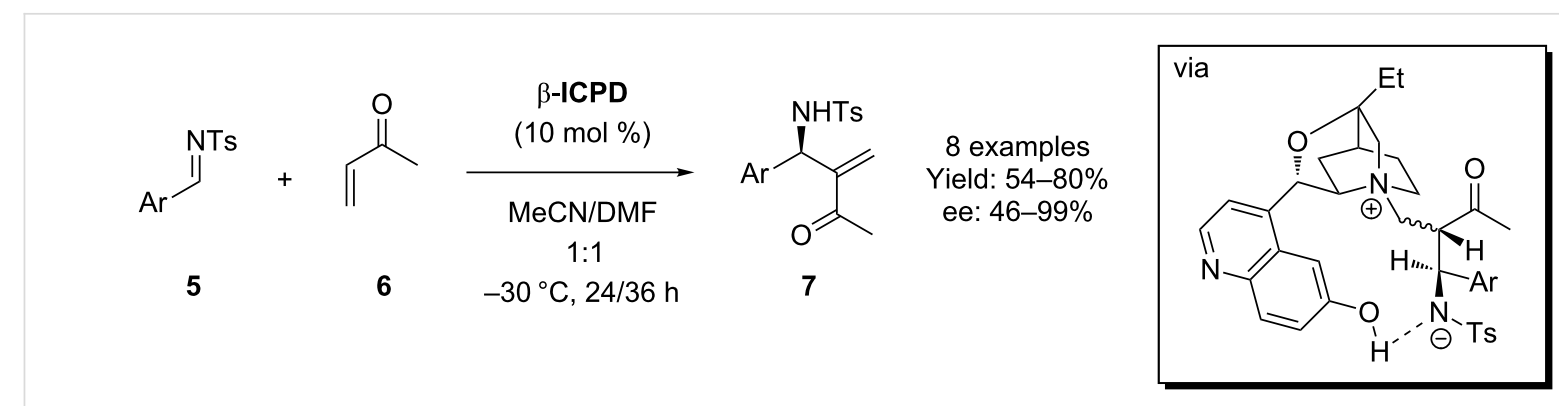

Scheme 2: Use of $\beta-I C P D$ in an aza-MBH reaction.

(a)

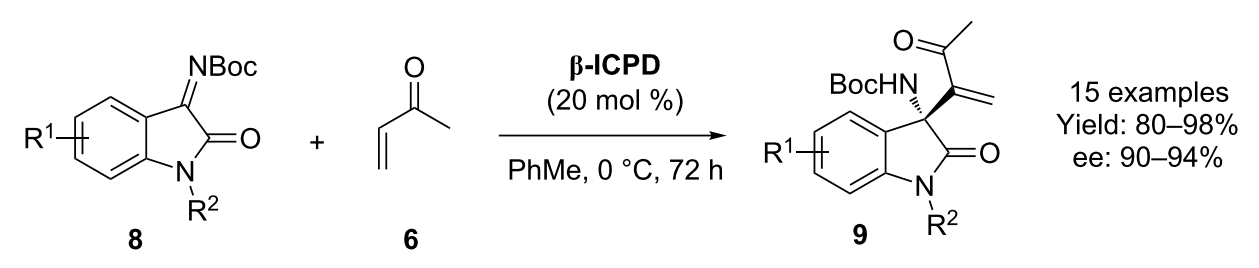

(b)<smiles>[R]c1ccc2c(c1)[C@](N)(C(=C)C=O)C(=O)N2[R]</smiles>

(S)-11

ee: $95-98 \%$<smiles>C=CC=O</smiles><smiles>[R]c1ccc2c(c1)N([R])C(=O)C2=NOC(C)(C)C</smiles>

8

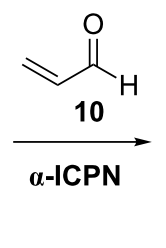

$\mathrm{R}$<smiles>[R1]c1ccc2c(c1)[C@](N)(C(=C)C(C)=O)C(=O)N2[R]</smiles>

(R)-11

ee: $83-96 \%$

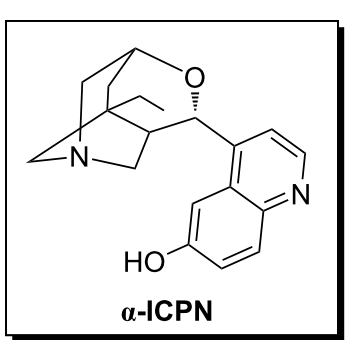

Scheme 3: (a) The isatin motif is a common feature for MBH processes catalyzed by $\beta$-ICPD, as demonstrated by Shi and Li and co-workers. (b) Takizawa and co-workers demonstrated similar chemistry, but also utilized the catalyst $\alpha$-ICPN (inset).

good selectivity [22]. Interestingly, replacing the Boc group with an ethyl carbamate decreased the yield and enantioselectivity dramatically, as did having a substituent at the 4-position of the ketimine. In a related study, Takizawa and co-workers demonstrated that the quinine derived organocatalyst, $\boldsymbol{\alpha}$-ICPN [23] produced the enantiomeric product in a similar process using acrolein $\mathbf{1 0}$ as the conjugate partner (Scheme 3b) [24].

Chen and co-workers developed an aza-MBH process using B-ICPD in the reaction between $N$-sulfonyl-1-aza-1,3-butadienes and activated alkenes (Scheme 4) [25]. In this report, optimal selectivity required $(R)$-BINOL as a co-catalyst (see inset for proposed catalytic transition state $-(R)$-BINOL shown in red). Furthermore, the utility of the adducts obtained was demonstrated through their conversion to a number of useful constructs (e.g., 16 and 17).

In reactions very much related to the $\mathrm{MBH}$ process, isatin derivatives have also proven to be particularly suited to the reaction of MBH-like products [26-28]. In these processes, the tertiary amine adds into the conjugate ester as with the $\mathrm{MBH}$ reaction, but instead of the resulting $\mathrm{C} 3$-ammonium enolate reacting with an electrophile, an $\mathrm{E} 1 \mathrm{cB}$ elimination of the carbonate occurs to generate another conjugated system. This can then undergo an attack by a Michael donor; elimination of the catalyst then generates the exo-methylene adduct. For example, $\mathrm{Lu}$ and co-workers have used $\boldsymbol{\beta}$-ICPD to react isatin-derived $\mathrm{MBH}$ carbonates 18 with nitroalkanes 19 [29]. The resulting adducts 20 could be converted to the corresponding spiroxindole 21 via a $\mathrm{Zn} / \mathrm{HOAc}$ mediated reduction of the nitro functionality (Scheme 5).

Similarly, Kesavan and co-workers reacted 3-O-Boc-oxindoles 23 with $\mathrm{MBH}$ carbonates $\mathbf{2 2}$ to generate a range of spirocyclic scaffolds containing $\alpha$-exo-methylene- $\gamma$-butyrolactone 24 again using $\boldsymbol{\beta}$-ICPD (Scheme 6) [30].

\section{Nazarov cyclization}

An asymmetric Nazarov cyclization has been developed by Frontier and co-worker using $\boldsymbol{\beta}$-ICPD through a mechanism 
(a)<smiles>[R]C=CC(=[N+])C(=O)OCC</smiles>

12

or

$\mathrm{R}^{1}$<smiles>[Y]C#CC(=[Sn])OCC</smiles>

13<smiles>[R]C=C[C@]([NH3+])(C(=C)C=O)C(=O)OCC</smiles>

14

or

10 $(10 \mathrm{~mol} \%)$

(R)-BINOL

(10 mol \%)

THF, $-40^{\circ} \mathrm{C}, 48 \mathrm{~h}$

$\mathrm{R}$<smiles>[R]C#C[C@]([NH3+])(C(=C)C=O)C(=S)OCC</smiles>

18 examples

Yield: $70-96 \%$

ee: $60-92 \%$

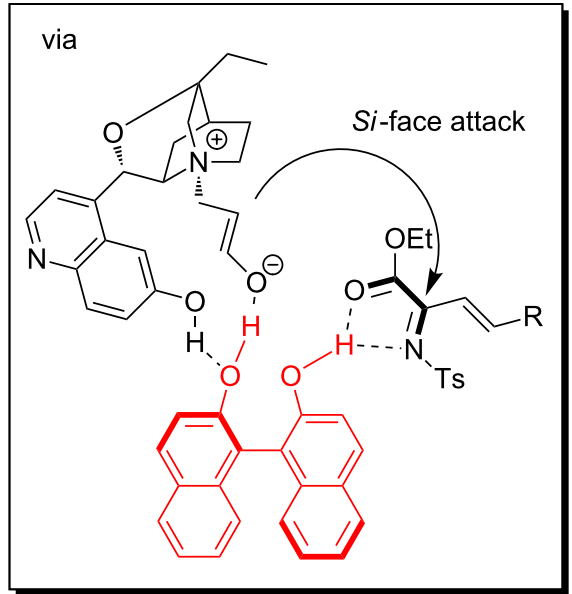

(b)

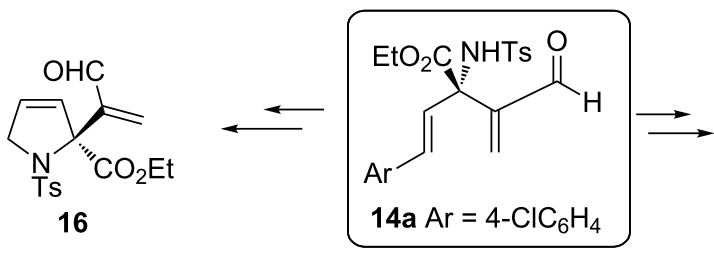

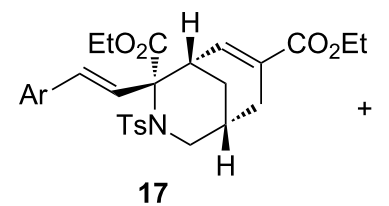

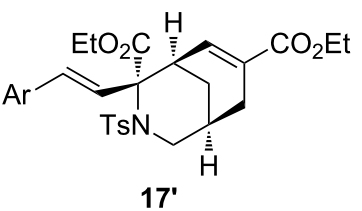

Scheme 4: (a) Chen's asymmetric MBH reaction. Good selectivity was dependent upon the presence of $(R)$-BINOL (shown in red) as well as $\beta$-ICPD (b) Diverse structures were obtained from the MBH adduct 14a.<smiles>[R1]c1ccc2c(c1)C(OC(=O)OC)(C(=C)OC)C(=O)N2C</smiles>

18<smiles>[R]C[N+](=O)[O-]</smiles>

19

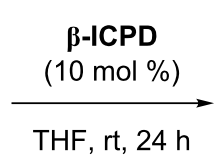

THF, rt, $24 \mathrm{~h}$<smiles>[R]C(=C)[C@]1(C(=O)OC)C(=O)Nc2ccccc21</smiles>

17 examples Yield: $40-68 \%$

dr: $2: 1$ to $5: 1$ ee (major): $84-98 \%$
$\underset{\mathrm{Zn} / \mathrm{HOAc}}{\stackrel{\mathrm{R}^{1} / \mathrm{R}^{2}=\mathrm{H}}{\longrightarrow}}$

reflux, $81 \%$<smiles>C=C1C(=O)NC[C@]12C(=O)Nc1ccccc12</smiles>

21

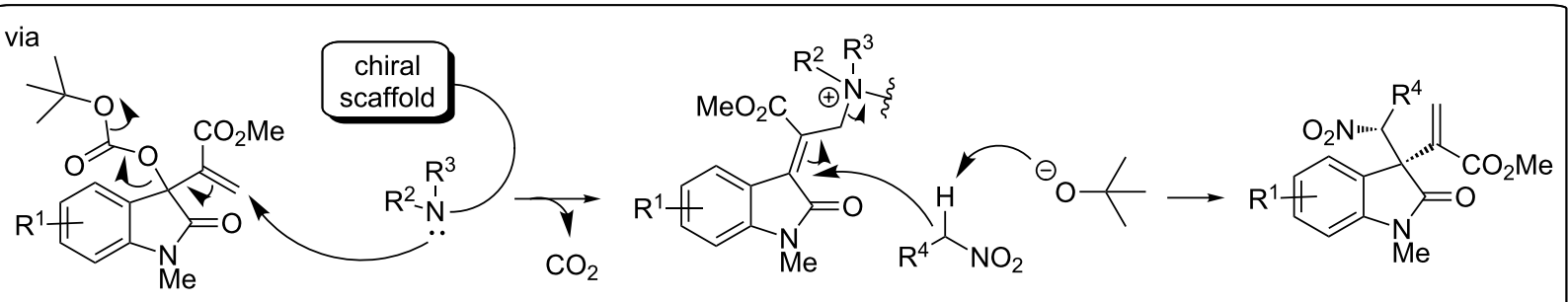

Scheme 5: Lu and co-workers synthesis of a spiroxindole.

that is reminiscent of the MBH reaction (Scheme 7) [31]. In this process however, the tertiary amine adds to the conjugated system $\mathbf{2 5}$ in a 1,6-fashion to generate intermediate enolate $\mathbf{2 6}$. This undergoes a single bond rotation to set up a $4 \pi$-electrocyclization, generating second intermediate 27. Elimination of the tertiary amine then gives $\gamma$-methylene cyclopentenone $\mathbf{2 8}$.

\section{1,2-Addition reactions}

\section{Henry reaction}

The use of cupreine and cupreidine derivatives in the addition of nitroalkanes to carbonyl compounds was first demonstrated by Deng and co-workers [32-34]. In this excellent study, catalysts substituted with benzyl at the 9-OH position gave the best 
<smiles>C=C(C(=O)OCC)[C@@H](OC(=O)OCC)c1cc[R1]cc1</smiles>

22<smiles>[R]c1ccc2c(c1)[C@H](OC(C)(C)C)C(=O)N2CC#C</smiles>

23 (i) $\beta$-ICPD

$(10 \mathrm{~mol} \%)$

mesitylene

(ii) TFA, DCM<smiles>[R2]c1ccc2c(c1)[C@]1(OC(=O)C(=C)[C@H]1[Al])C(=O)N2CC#C</smiles>

14 examples Yield: $76-92 \%$ dr: $4: 1$ to $20: 1$ ee: $74-98 \%$

Scheme 6: Kesavan and co-workers' synthesis of spiroxindoles.

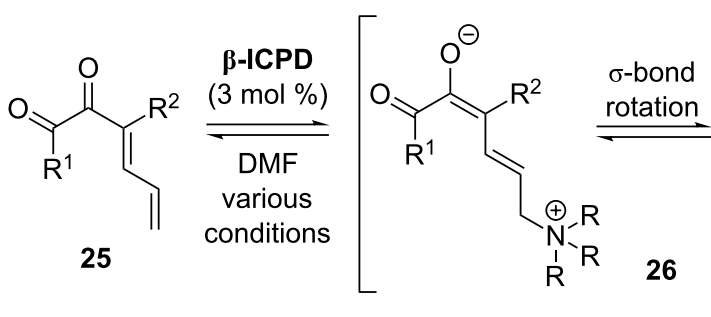

Scheme 7: Frontier's Nazarov cyclization catalyzed by $\boldsymbol{\beta}$-ICPD. results (CPD-30, Scheme 8). This report also demonstrated that the enantiomer of $\beta$-nitroester $\mathbf{3 1}$ could be obtained using the corresponding pseudoenantiomeric organocatalyst with comparable results.

More recently, Johnson and co-worker used the $o$-toluoyl derived organocatalyst CPD-33 to effect a dynamic kinetic asymmetric transformation of racemic $\beta$-bromo- $\alpha$-keto esters 32 (Scheme 9a) [35]. The mechanism, deduced from deuterium labeling studies, proposes that one of the two enantiomers of $\mathbf{3 2}$ will react more rapidly with nitromethane in the presence of the cupreidine catalyst CPD-33. As these enantiomers equilibrate via 35 in the presence of the catalyst, a dynamic kinetic asymmetric reaction occurs (Scheme 9b).

\section{Friedel-Crafts reaction}

Pedro and co-workers have utilized a 9-OH benzoyl derivatised cupreine CPN-38 to effect a Friedel-Crafts reaction of 2-naph- thols 36 with benzoxathiazine 2,2-dioxides 37 (Scheme 10). These cyclic imides, derived from salicylic aldehydes, have a rigid structure which prevents $E / Z$-isomerization, allowing for greater control over the stereochemical outcome of the reaction [36]. This work was based on a related scheme from Chimni and co-worker, who used CPN derivatised at the 9-OH with 1-naphthoyl in the addition of sesamol to a range of $N$-sulfonylimines [37].

\section{1,4-Conjugate additions}

Deng and co-workers have contributed many examples of 1,4additions that have been facilitated by CPD and CPN derived catalysts. For example, and amongst the earliest examples in the field, underivatized CPD or CPN were used in the addition of dimethyl malonate (40) to a range of nitrostyrenes $\mathbf{4 1}$, giving the resulting adducts with excellent enantioselectivity (Scheme 11a) [38]. Subsequent reports by Deng and co-workers include, amongst many varieties of Michael acceptor and donor

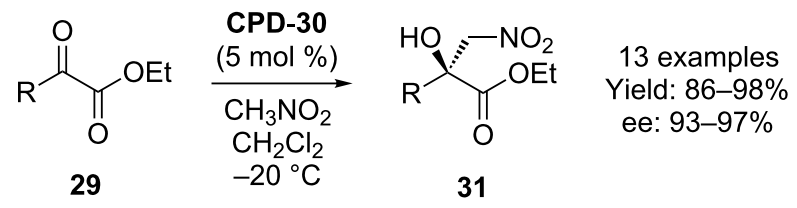

Scheme 8: The first asymmetric nitroaldol process catalyzed by a 6'-OH cinchona alkaloid.

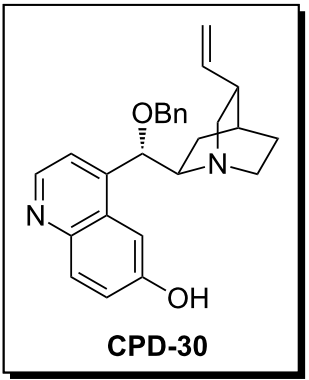


(a)<smiles>[R]C(Br)C(=O)C(=O)OC(C)C</smiles>

$( \pm)-32$

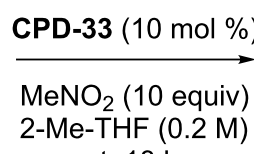
$\mathrm{rt}, 18 \mathrm{~h}$<smiles>[R]C(Br)C(O)(C[N+](=O)[O-])C(=O)OCC</smiles>

34

9 examples

Yield: $92-98 \%$

ee: $74-92 \%$

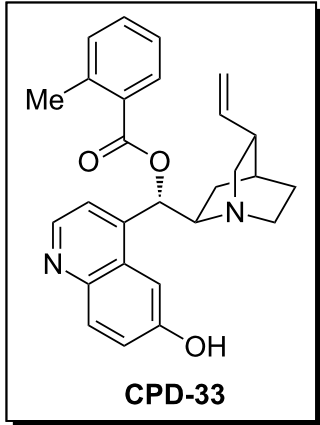

(b)<smiles>CC(C)OC(=O)C(=O)C(Br)Cc1ccccc1</smiles><smiles>COC(=O)c1ccccc1</smiles><smiles>CC(C)OC(=O)C(O)(C(=O)OC(C)C)C(Br)Cc1ccccc1</smiles><smiles>CC(C)OC(=O)/C([O-])=C(/Br)Cc1ccccc1</smiles><smiles>[134Co]</smiles>

35<smiles>O=C(OC(F)F)C(=O)C(Br)CPc1ccccc1</smiles>
$\mathrm{MeNO}_{2} \cdot \mathrm{CPD}-33$ slow<smiles>CC(C)OC(=O)C(O)(C(=O)OC(C)C)[C@H](Br)Cc1ccccc1</smiles>

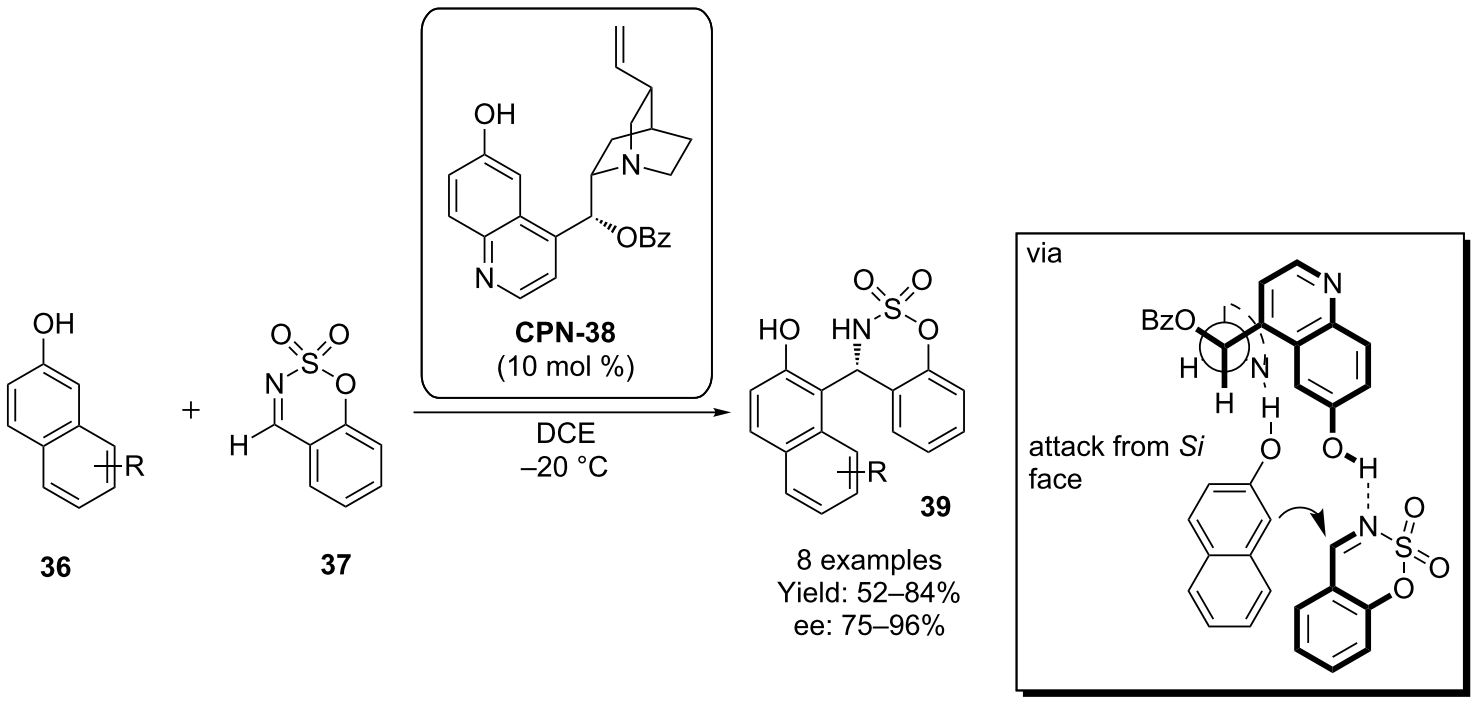

Scheme 10: Cupreine derivative $\mathbf{3 8}$ has been used in an organocatalytic asymmetric Friedel-Crafts reaction.

with various CPN/CPD derivatives [39-41], an example where $\beta$-ketoesters are used as the nucleophilic component [42]. It is on the basis of this work that Lin and co-workers were recently inspired to use the (de-Me-DHQ) 2 PHAL catalyst HCPD-44 in the addition of $\alpha$-substituted nitro acetates $\mathbf{4 3}$ also into nitroolefins 41 (Scheme 11b) [43-46]. 
(a)<smiles>[R]C=C[N+](=O)[O-]</smiles><smiles>[R]C(C[N+](=O)[O-])C(C(=O)OC)C(=O)OC</smiles>

(S) -42

Yield: $81-99 \%$ ee: $94-98 \%$<smiles>[R]C(C[N+](=O)[O-])C(C(=O)OC)C(=O)OC</smiles>

Yield: $82-99 \%$ ee: $91-96 \%$

(b)

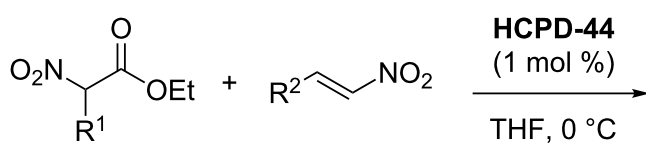

43
41<smiles>[R]C([R])(C[N+](=O)[O-])C([R])(C(=O)OCC)[N+](=O)[O-]</smiles>

45

19 examples Yield: $71-99 \%$ dr: $89: 11$ to $99: 1$ ee: $95-98 \%$

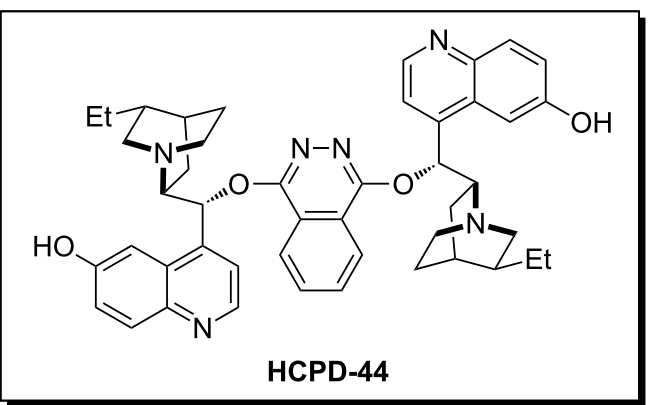

Scheme 11: Examples of 6'-OH cinchona alkaloid catalyzed processes include: (a) Deng's addition of dimethyl malonate into nitroolefins, and (b) Lin's similar process with $\alpha$-nitroesters using the symmetric hydrocupreidine system HCPD-44.

In a fascinating report, Melchiorre and co-workers use the 9-amino-CPD system CPD-48 to control the Michael addition of thiols $\mathbf{4 6}$ into $\alpha$-branched enones $\mathbf{4 7}$ via iminium ion catalysis (Scheme 12) [47]. This study found that the catalytic function could be modulated to induce diastereodivergent pathways by applying an external chemical stimulus (Scheme 12). Several conclusions were made from this study, one of which was that the hydrogen-bonding moiety of the 6'-OH in the catalyst is essential in directing the reaction towards the anti-diastereose- lective pathway. Secondly, the solvent was critical in the diastereocontrol of the reaction. This is put down to the fact that the solvent can have an important influence on the conformation of the flexible cinchona framework, which has a knock-on effect on the catalytic outcome. Interestingly, the chiral nature of the binol phosphoric acid catalyst (S)-49 in the anti-selective process was not thought to be hugely influential upon the stereochemical outcome. Indeed replacing it with diphenyl hydrogen phosphate (DPP) gave comparable results, ultimately

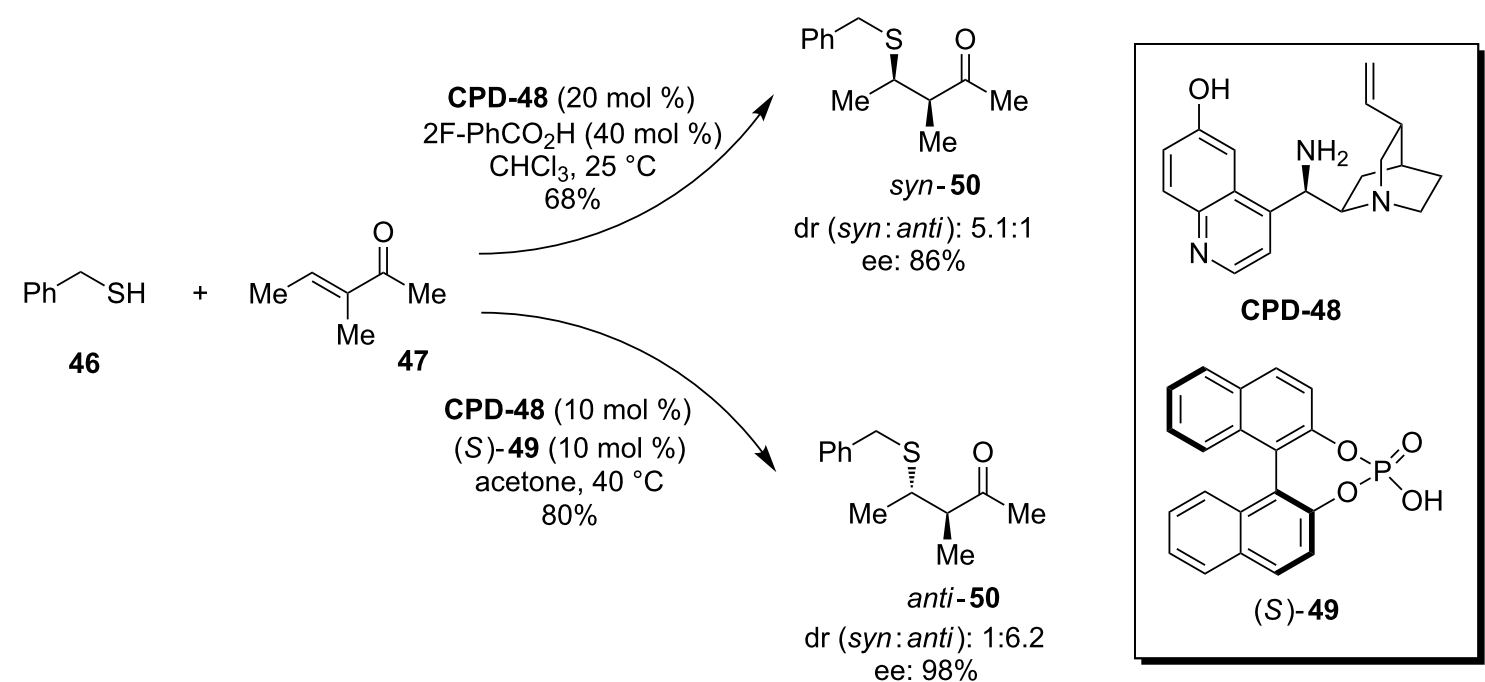

Scheme 12: A diastereodivergent sulfa-Michael addition developed by Melchiorre and co-workers. 
leading to a third conclusion - that the strong hydrogen-bonding ability of the phosphate anion will favour the anti-selective pathway.

Melchiorre and co-workers have also succeeded in using the related cupreine organocatalyst $\mathbf{C P N - 5 1}$ in a direct vinylogous Michael addition reaction [48]. In this process, cyclic enones $\mathbf{5 2}$ are added to nitroalkenes $\mathbf{4 1}$ using dienamine catalysis (Scheme 13). Although no model is suggested with respect to how the 6'-OH is involved, it is clearly of importance as the analogous 6'-OMe derived cupreine catalyst gives significantly lower conversions and selectivities.

Simpkins and co-workers have used CPD-30 in the reaction of triketopiperidines (TKPs) $\mathbf{5 4}$ with a variety of enones with very good selectivity (Scheme 14a) [49]. Interestingly, with different types of acceptor, a cyclization event occurred leading to the bicyclic hydroxydiketopiperizine system 56 with very high diasterecontrol. Once again, the authors invoke a critical role for the 6'-OH group in the co-ordination and activation of the electrophile in these processes.

\section{Cyclopropanations}

Not unrelated to the Michael addition in a mechanistic sense, is the asymmetric cyclopropanation using dimethyl bromomalonate (57) and some form of Michael acceptor. In this process, the enolate resulting from the initital conjugate addition attacks the $\mathrm{C}-\mathrm{Br}$ bond to form a three-membered ring. In our work in this area, we designed a new cupreine derived catalyst HCPN59 to add dimethyl bromomalonate (57) to a conjugated cyanosulfone 58 (Scheme 15). Our expectations were that the highly functionalized adduct $\mathbf{6 0}$ that resulted would be able to undergo a variety of chemistries, allowing access to a number of diverse scaffolds. This was demonstrated through the synthe-<smiles>[R1]CC1=CC(=O)CCC1</smiles><smiles>[R]C=C[N+](=O)[O-]</smiles>

CPN-51 (20 mol \%) $2 \mathrm{~F}-\mathrm{PhCO}_{2} \mathrm{H}$ (30 $\mathrm{mol} \%$ ) or $2 \mathrm{OH}-\mathrm{PhCO}_{2} \mathrm{H}$ (40 mol \%) PhMe, rt, $48 \mathrm{~h}$

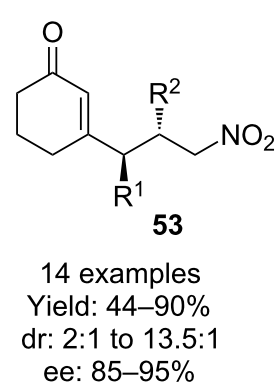

Scheme 13: Melchiorre's vinylogous Michael addition.

(a)<smiles>[Y]C1NC(=O)C(=O)NC1=O</smiles>

54a: $Y=\mathrm{CO}_{2} \mathrm{Me}$ 54b: $Y=H$

(b)<smiles>[Y]C1NC(=O)C(=O)C(=O)C1=O</smiles>

54a: $Y=\mathrm{CO}_{2} \mathrm{Me}$ 54b: $Y=H$
CPD-30 (10 mol \%)<smiles>[R]C=CC([R])=O</smiles>

3-6 h

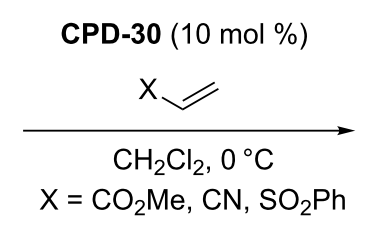<smiles>[R]C(=O)CC([R2])C1([Y])NC(=O)C(=O)NC1=O</smiles>

55

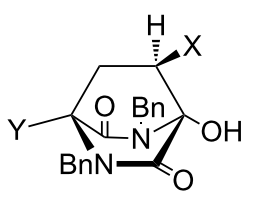

56
13 examples

Yield: $80-99 \%$

ee: $76-98 \%$

of these, 2 examples where $\mathrm{R}^{2}=\mathrm{H}, \mathrm{dr}:>19: 1$

6 examples Yield: $82-99 \%$ dr: $>19: 1$ ee: $66-94 \%$

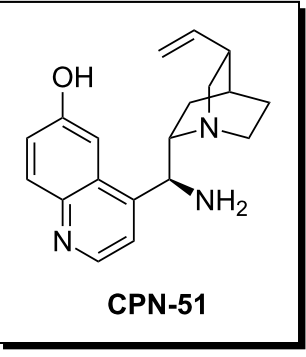

CPN-51 
(a)<smiles>COC(=O)C(Br)C(=O)OC</smiles>

57<smiles>[10BH]</smiles>

HCPN-59

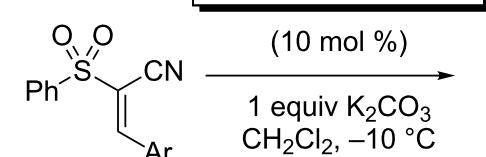

58

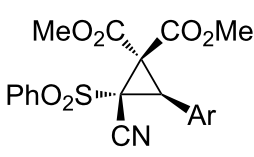

60

9 examples

Yield: 73 to $>99 \%$ dr: $>19: 1$ ee (after recrystallization): $60-96 \%$

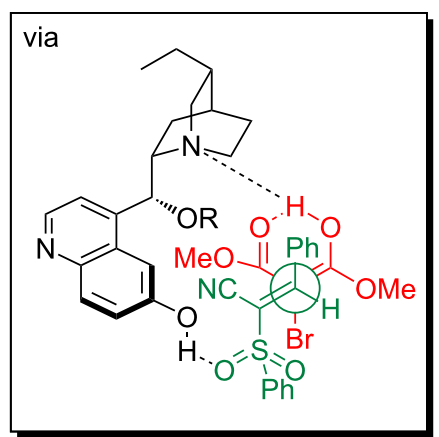

(b)<smiles>COC(=O)[C@]12CNC[C@]1(S(=O)(=O)O)[C@H]2c1ccccc1</smiles>

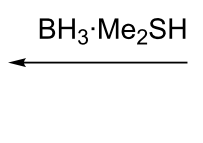

61<smiles>COC(=O)C1(C(C)=O)C(c2ccccc2)C1(C#N)[SnH]c1ccccc1</smiles>

$60 a$ $\underset{\text { heat }}{\stackrel{\mathrm{Mg}, \mathrm{MeOH}}{\longrightarrow}}$

Scheme 15: Hydrocupreine catalyst HCPN-59 can be used in an asymmetric cyclopropanation.

sis of the corresponding 3-azabicyclo[3.1.0]hexane system $\mathbf{6 1}$ and the $\delta^{3}$-amino acid precursor 62 [50].

\section{Epoxidations and oxaziridinations}

A variety of cinchona-derived phase transfer catalysts have been employed in the asymmetric epoxidation [51,52], but only one utilizes the free 6'-OH. In this report by Berkessel and co-workers, cupreine and cupreidine PTCs HCPN-65 and HCPD-67 were used in the epoxidation of the $c i s-\alpha, \beta$-unsaturated ketone 63 with sodium hypochlorite [53,54]. Interestingly, the use of these pseudoenantiomers did not lead to similar magnitudes of stereoselection in the opposite enantiomers of epoxide 64 that they produced, as is often the case with cinchona alkaloid catalyzed processes. However, the role of the 6 '-OH was clearly important when directly compared with the equivalent 6'-OiPr catalysts 66 and 68 (Scheme 16).

Jørgensen and co-workers have used another anthracenyl-modified hydrocupreidine HCPD-70 in an enantioselective oxaziridination using mCPBA as the oxidant (Scheme 17) [55]. The authors propose that the quinuclidine nitrogen is protonated by the peracid, giving rise to a tight ion pair, whilst the 6'-OH coordinates to the sulfonyl group oxygen, thus bringing the reactants together. Subsequent reaction then leads to an intermedi- ate $\alpha$-aminoperoxy structure, which quickly collapses to the oxaziridine 71 .

\section{Formation of $\mathrm{C}-\mathrm{X}$ bonds $\alpha$-functionalisation}

In two separate reports, Zhou and co-workers demonstrate the use of di-tert-butyl azodicarboxylate 72 (DBAD) in the direct amination of several different substrates using $\beta$-isocupreidine ( $\beta$-ICPD). In the first of these, $\alpha$-substituted nitoacetates $\mathbf{7 3}$ are used [56], and in the second 3-thiooxindoles $\mathbf{7 5}$ are employed (Scheme 18) [57]. Unfortunately, in neither of these papers is the absolute stereochemistry elucidated.

Finally, Meng and co-workers used cupreidine (CPD) in the $\alpha$-hydroxylation of indenones (where $n=1$ in 77) using cumyl hydroperoxide (Scheme 19) [58]. Interestingly, the 3,4-dihydronaphthalen-1(2H)-one derivative (where $n=2$ in 77) did not afford any detectable product.

\section{Transamination}

A range of $\alpha$-amino acid derivatives have been accessed by Shi and co-workers who developed an organocatalytic transamination process using the cupreine catalyst $\mathbf{C P N - 8 1}$, which is substituted with $n$-butyl at the 9-OH position [59]. In this report, the $\alpha$-ketoester 79 was reacted with the primary amine 


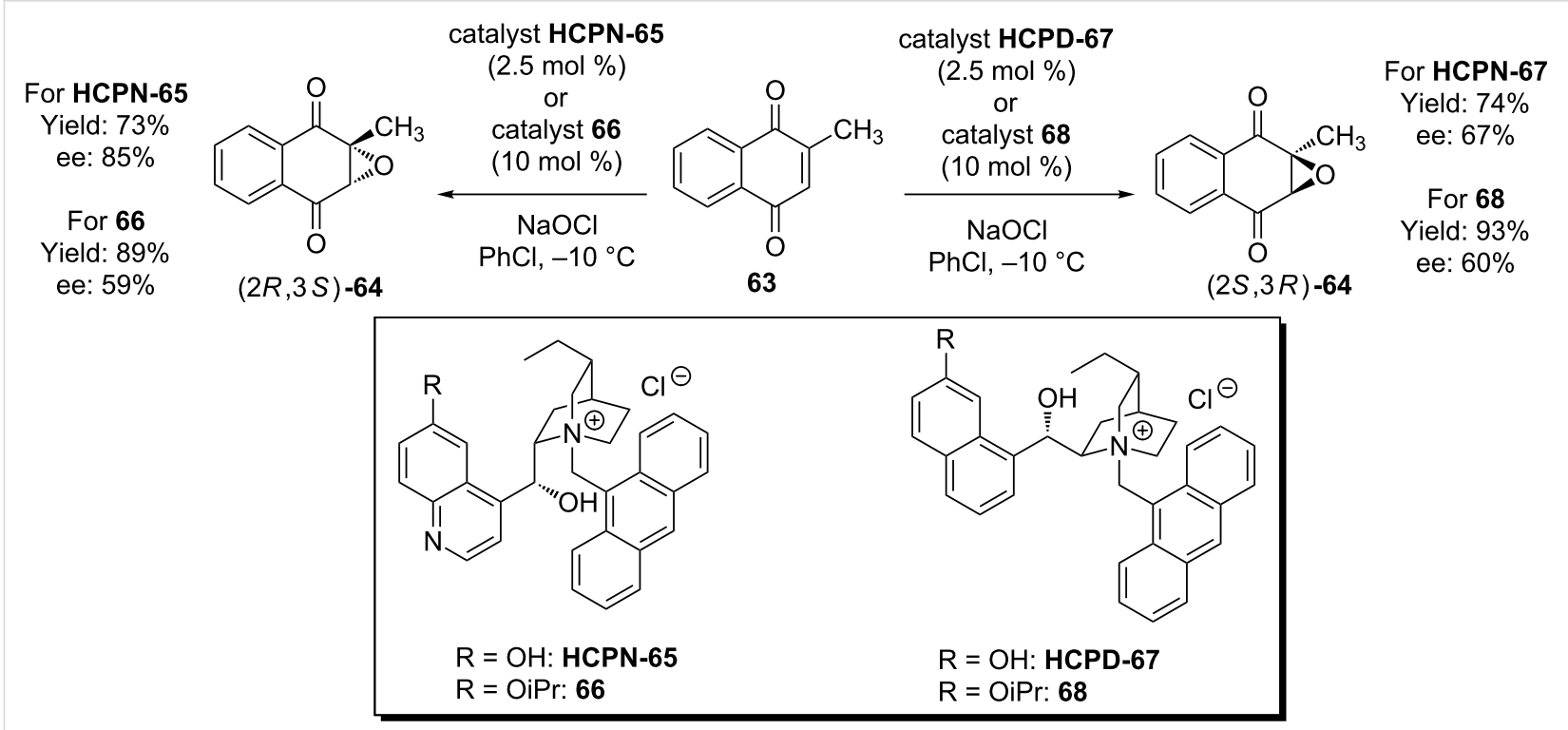

Scheme 16: The hydrocupreine and hydrocupreidine-based catalysts HCPN-65 and HCPD-67 demonstrate the potential for phase transfer catalyst derivatives of the 6'-OH cinchona alkaloids to be used in asymmetric synthesis.

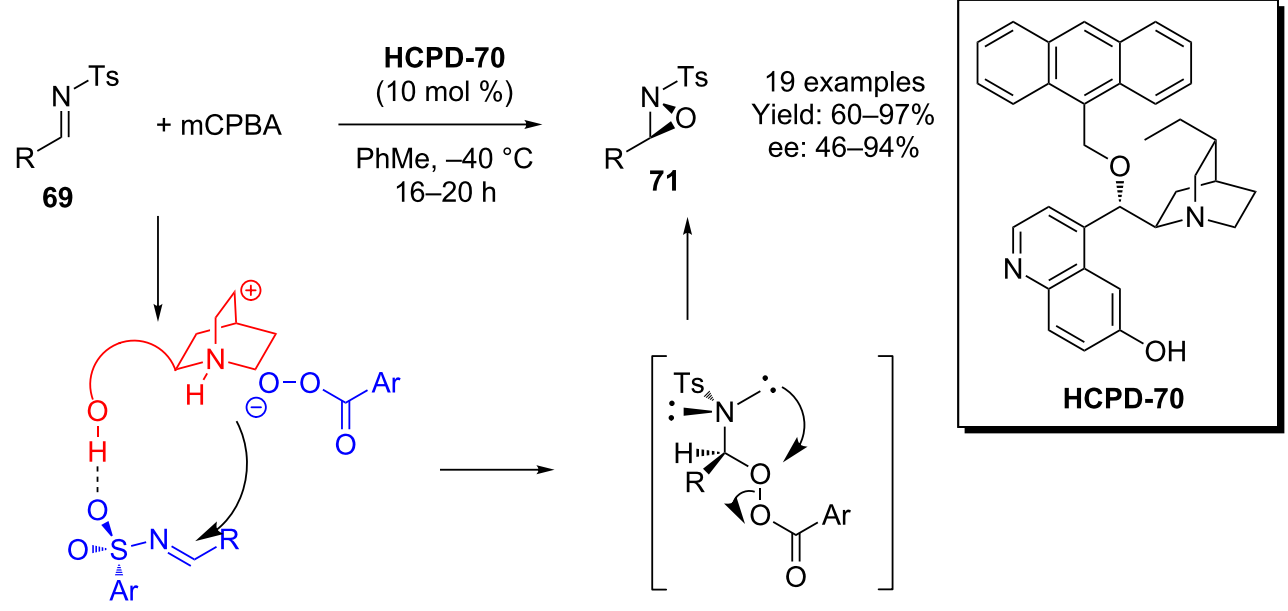

Scheme 17: Jørgensen's oxaziridination.

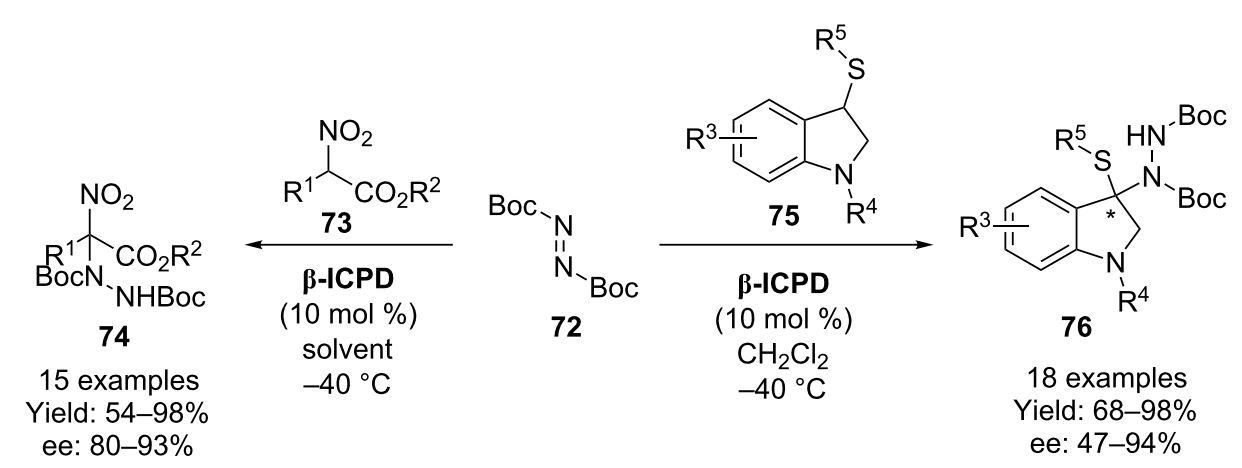




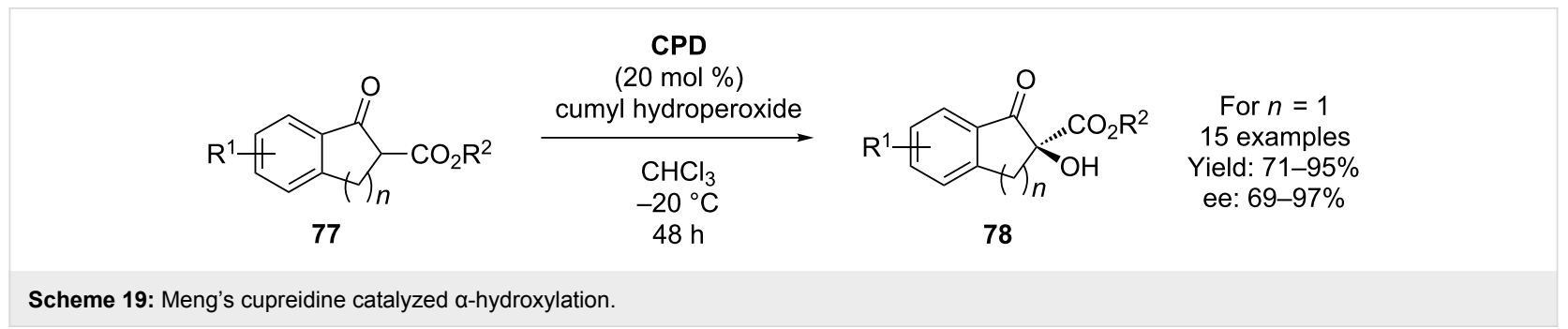

$o-\mathrm{ClC}_{6} \mathrm{H}_{4} \mathrm{CH}_{2} \mathrm{NH}_{2} \mathbf{8 0}$ in the presence of the catalyst. Once again, the role of the 6 '-OH functionality is shown to be critical in the orchestration of the reaction process, as depicted in the proposed transition state model (Scheme 20).

\section{Cycloadditions}

The $[4+2]$ cycloaddition of benzofuran-2(3H)-one derivatives $\mathbf{8 4}$ with methyl allenoate $\mathbf{8 5}$ to give the corresponding dihydropyran fused benzofuran precursors 86 using $\boldsymbol{\beta}$-ICPD has been achieved by Li and Cheng and co-workers (Scheme 21a) [60-63]. A large number of computational studies were conducted to explain the enantioselection of the process, resulting in the transition state shown which depicts a critical methanol bridge, explaining the need for this as an additive within the reaction to give optimal stereoselectivities. Similarly, $\mathrm{Xu}$ and co-workers have used $\boldsymbol{\beta}$-ICPD in the cycloaddition between isatin framework $\mathbf{8 7}$ and olefinic azlactones $\mathbf{8 8}$ to give adduct 89 (Scheme 21b) [64].

Finally, in a remarkable demonstration of diversity-oriented synthesis, Chen and co-workers have shown that simply by switching the type of 6'-OH cinchona-derived catalyst used, two different products can be obtained in their reaction between the 2-cyclohexenone MBH derivative 90 and isatylidene malontirile 91, one of which is the [4+2] adduct 92, albeit achieved in a step-wise manner (Scheme 21c) [65]. Disappoint-

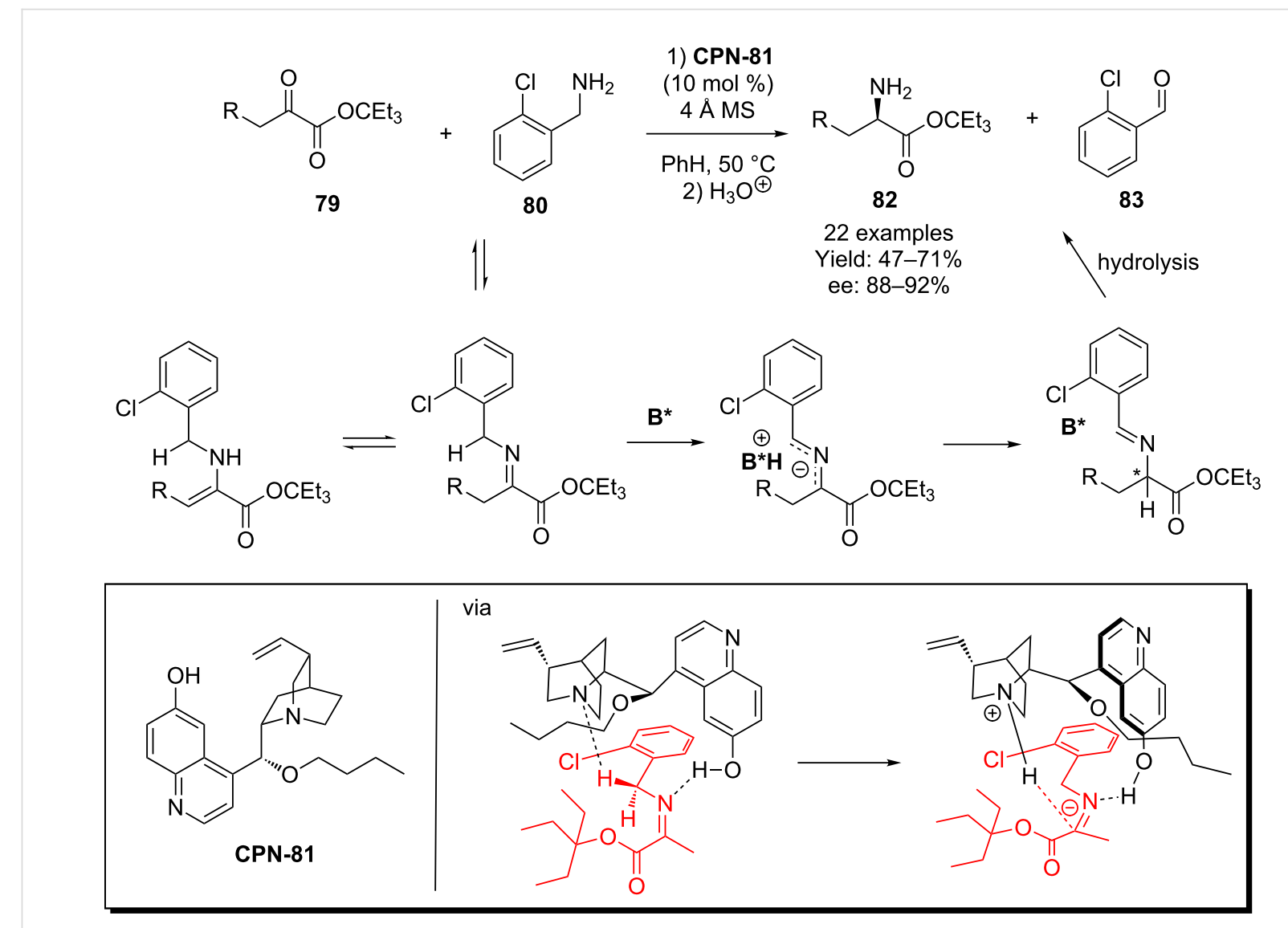

Scheme 20: Shi's biomimetic transamination process for the synthesis of $\alpha$-amino acids. 


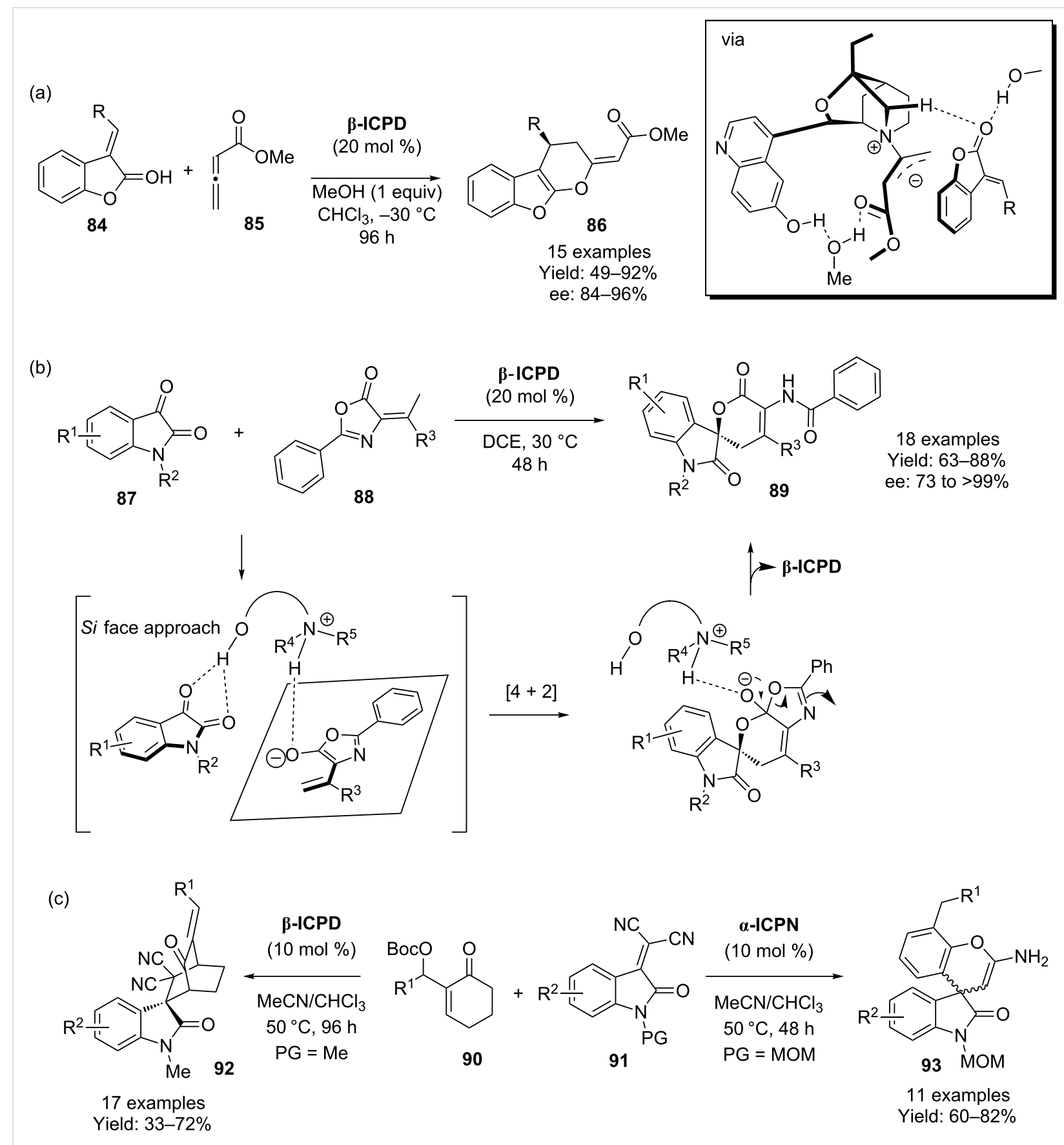

Scheme 21: $\beta$-Isocupreidine catalyzed [4 + 2] cycloadditions.

ingly, though not uninteresting, is the fact that there is no enantioinduction for either of these processes.

$\beta$-Isocupredeine has also been used in the $[2+2]$-addition between 2-thioxoacetates 94 and allenoates 95 to give the corresponding thietanes 96. In another example of how a different catalyst can lead to a different product, the authors demonstrated that the use of DABCO led instead to the [4+2] adduct (Scheme 22) [66].

\section{Domino reaction}

Although it could be argued that some of the reactions within this review are already domino reactions (e.g., $\mathrm{MBH}$, and the cyclopropanation), a recent and clearer example of the use of a 6 '-OH cinchona derived catalyst in such a process comes from the laboratory of Samanta and co-workers $[67,68]$. They have demonstrated an enantioselective domino reaction between 3 -formylindoles 98 and nitroolefins $\mathbf{4 1}$ to generate the corresponding tricyclic adducts 99 using cupreidine derivative CPD- 


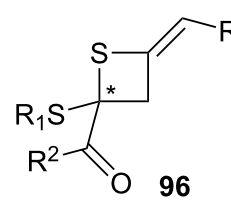

6 examples

Yield: $71-94 \%$

ee: $8-88 \%$

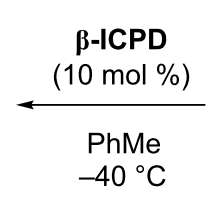

$R^{2} \prod_{S 4}^{O} S_{94}^{1}+$<smiles>[R]C(=O)C=C=C</smiles>

95

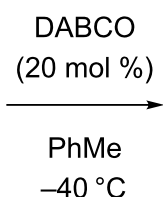<smiles>[R]C=C1CSC([R3])=C([R])O1</smiles>

15 examples

Yield: $43-81 \%$

Scheme 22: $\beta$-Isocupreidine catalyzed [2+2] cycloaddition.<smiles>CC(=O)Cc1[nH]c2ccccc2c1C=O</smiles>

98

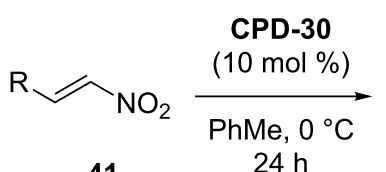

41<smiles>[R]C1C(C(C)=O)C2Nc3ccccc3C2C(O)C1[N+](=O)[O-]</smiles>

3 examples

Yield: 89-93\%

dr: $4: 1$

ee: $82-92 \%$

Scheme 23: A domino reaction catalyst by cupreidine catalyst CPD-30.

(a)<smiles>COc1cccc(O)c1O</smiles>

100<smiles>CC(C)(C)OC(=O)C1Cc2ccccc2C1=O</smiles>

101

\section{CPD-102}

(10 $\mathrm{mol} \%)$ $\mathrm{CH}_{2} \mathrm{Cl}_{2},-20^{\circ} \mathrm{C}$

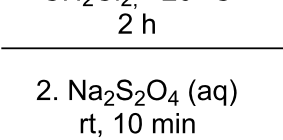

$\mathrm{rt}, 10 \mathrm{~min}$ ps- $-\mathrm{IO}_{4}$ (2 equiv)<smiles>COc1cc(C2(C(=O)OC(C)(C)C)Cc3ccccc3C2=O)cc(O)c1O</smiles>

103

Yield: $84 \%$

ee: $81 \%$

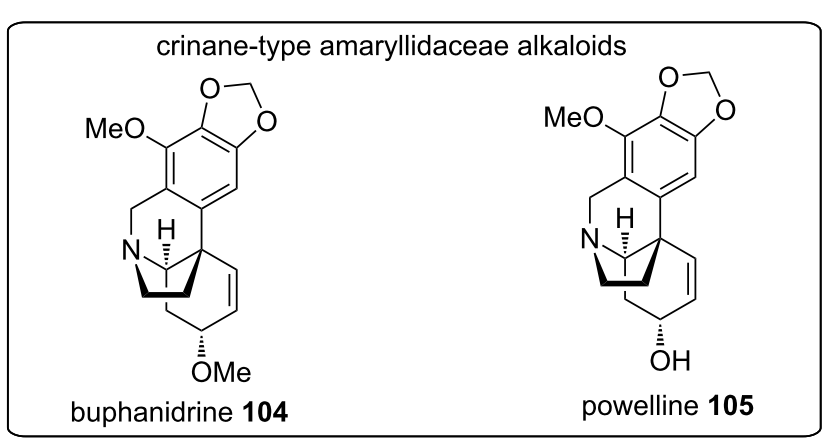

buphanidrine 104

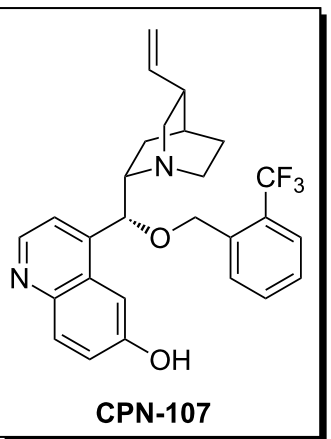

Scheme 24: (a) Dixon's 6'-OH cinchona alkaloid catalyzed oxidative coupling. (b) An asymmetric oxidative coupling en route to the attempted total synthesis of some amaryllidaceae alkaloids. 
30 (Scheme 23). Although the substrate scope for the enantioselective reaction is limited, the diastereoselectivities are reasonable, and the enantioselectivities are excellent.

\section{Other processes}

\section{Asymmetric oxidative coupling}

All carbon quaternary centers are prevalent in both natural and pharmaceutical compounds, but rank amongst the hardest to synthesize in a stereoselective manner. Dixon and co-workers have addressed this through the development of an asymmetric organocatalytic oxidative coupling - initially between 3-methoxycatechol (100) and tert-butyl 1-oxoindan-2-carboxylate (101) using an adamantane derivative of cupreidine CPD102 to give the corresponding adduct 103 in $84 \%$ yield and $81 \%$ ee (Scheme 24a) [69]. An attempt to develop this methodology towards an asymmetric total synthesis of buphanidrine (104) and powelline (105) led to the bespoke development of another cupreidine catalyst CPN-107. Unfortunately, although the resulting adduct 108 (after alkylation of the catechol) was produced in a $70 \%$ enantiomeric excess (Scheme 24b), subsequent steps that had worked with the racemic synthesis severely deteriorated this, preventing completion of the total synthesis $[70,71]$.

\section{Conclusion}

Cupreine and cupreidine and their derivatives have been demonstrated to be suited to a wide range of reaction processes, often with very good enantioinduction. In most cases these catalysts are easy to make from the corresponding cinchona alkaloids, making them attractive compounds for methodologists to have within their catalyst arsenal. They seem particularly suited to catalysis with systems that have an aromatic ring next to a five-membered ring - e.g., indoles, indenones, isatin etc. especially when it comes to the Morita-Baylis-Hillman reaction, although they are in no way limited to these, and one can only expect the prevalence of these remarkable bifunctional catalysts within the literature to increase over the coming years.

\section{Acknowledgements}

The University of Reading (to RF) and GW Pharmaceuticals, along with the BBSRC (BB/L015714/1 to LAB) are gratefully acknowledged for financial support.

\section{References}

1. Li, H.; Liu, X.; Wu, F.; Tang, L.; Deng, L. Proc. Natl. Acad. Sci. U. S. A. 2010, 107, 20625-20629. doi:10.1073/pnas.1004439107

2. Marcelli, T.; Hiemstra, H. Synthesis 2010, 1229-1279. doi:10.1055/s-0029-1218699

3. Okino, T.; Hoashi, Y.; Takemoto, Y. J. Am. Chem. Soc. 2003, 125, 12672-12673. doi:10.1021/ja036972z

4. Okino, T.; Hoashi, Y.; Furukawa, T.; Xu, X.; Takemoto, Y. J. Am. Chem. Soc. 2005, 127, 119-125. doi:10.1021/ja044370p
5. Vakulya, B.; Varga, S.; Csámpai, A.; Soós, T. Org. Lett. 2005, 7, 1967-1969. doi:10.1021/ol050431s

6. Li, B.-J.; Jiang, L.; Liu, M.; Chen, Y.-C.; Ding, L.-S.; Wu, Y. Synlett 2005, 603-606. doi:10.1055/s-2005-863710

7. McCooey, S. H.; Connon, S. J. Angew. Chem., Int. Ed. 2005, 44, 6367-6370. doi:10.1002/anie.200501721

8. Ye, J.; Dixon, D. J.; Hynes, P. S. Chem. Commun. 2005, 4481-4483. doi:10.1039/B508833J

9. Nodes, W. J.; Nutt, D. R.; Chippindale, A. M.; Cobb, A. J. A. J. Am. Chem. Soc. 2009, 131, 16016-16017. doi:10.1021/ja9070915

10. Rajkumar, S.; Shankland, K.; Brown, G. D.; Cobb, A. J. A. Chem. Sci. 2012, 3, 584-588. doi:10.1039/C1SC00592H

11. Rajkumar, S.; Shankland, K.; Goodman, J. M.; Cobb, A. J. A. Org. Lett. 2013, 15, 1386-1389. doi:10.1021/ol400356k

12. Al-Ani, W.; Shankland, K.; Cobb, A. J. A. Synlett 2016, 27, 17-20. doi:10.1055/s-0035-1560504

13. Marcelli, T.; van Maarseveen, J. H.; Hiemstra, $H$. Angew. Chem., Int. Ed. 2006, 45, 7496-7504. doi:10.1002/anie.200602318

14. Ingemann, S.; Hiemstra, H. Cinchonas and Cupreidines. In Comprehensive Enantioselective Organocatalysis: Catalysts, Reactions, and Applications; Dalko, P. I., Ed.; Wiley-VCH: Weinheim, Germany, 2013. doi:10.1002/9783527658862.ch6

15. Morita, K.-i.; Suzuki, Z.; Hirose, H. Bull. Chem. Soc. Jpn. 1968, 41, 2815. doi:10.1246/bcsj.41.2815

16. Morita, K. Japan Patent 6803364, 1968.

17. Baylis, A. B.; Hillman, M. E. D. German Patent 2155113, May 10, 1972.

18. Aggarwal, V. K.; Fulford, S. Y.; Lloyd-Jones, G. C. Angew. Chem., Int. Ed. 2005, 44, 1706-1708. doi:10.1002/anie.200462462

19. Iwabuchi, Y.; Nakatani, M.; Yokoyama, N.; Hatakeyama, S. J. Am. Chem. Soc. 1999, 121, 10219-10220. doi:10.1021/ja992655+

20. Gaunt, M. J.; Johansson, C. C. C. Chem. Rev. 2007, 107, 5596-5605. doi:10.1021/cr0683764

21. Shi, M.; Xu, Y.-M. Angew. Chem., Int. Ed. 2002, 41, 4507-4510. doi:10.1002/1521-3773(20021202)41:23<4507::AID-ANIE4507>3.0.CO ;2-I

22. Hu, F.-L.; Wei, Y.; Shi, M.; Pindi, S.; Li, G. Org. Biomol. Chem. 2013, 11, 1921-1924. doi:10.1039/C3OB27495K

23. Nakamoto, Y.; Urabe, F.; Takahashi, K.; Ishihara, J.; Hatakeyama, S. Chem. - Eur. J. 2013, 19, 12653-12656. doi:10.1002/chem.201302665

24. Yoshida, Y.; Sako, M.; Kishi, K.; Sasai, H.; Hatekeyama, S.; Takizawa, S. Org. Biomol. Chem. 2015, 13, 9022-9028. doi:10.1039/c5ob00874c

25. Yao, Y.; Li, J.-J.; Zhou, Q.-Q.; Dong, L.; Chen, Y.-C. Chem. - Eur. J. 2013, 19, 9447-9451. doi:10.1002/chem.201301558

26. Mohammadi, S.; Heiran, R.; Herrera, R. P.; Marqués-López, E. ChemCatChem 2013, 2131-2148. doi:10.1002/cctc.201300050

27. Hong, L.; Wang, R. Adv. Synth. Catal. 2013, 355, 1023-1052. doi:10.1002/adsc.201200808

28. Dalpozzo, R.; Bartoli, G.; Bencivenni, G. Chem. Soc. Rev. 2012, 41 , 7247-7290. doi:10.1039/c2cs35100e

29. Chen, G.-Y.; Zhong, F.; Lu, Y. Org. Lett. 2012, 14, 3955-3957. doi:10.1021/ol301962e

30. Jayakumar, S.; Muthusamy, S.; Prakash, M.; Kesavan, V. Eur. J. Org. Chem. 2014, 1893-1898. doi:10.1002/ejoc.201301684

31. Huang, Y.-W.; Frontier, A. J. Tetrahedron Lett. 2015, 56, 3523-3526. doi:10.1016/j.tetlet.2014.12.136

32. Li, H.; Wang, B.; Deng, L. J. Am. Chem. Soc. 2006, 128, 732-733. doi:10.1021/ja057237। 
33. Cochi, A.; Métro, T.-X.; Pardo, D. G.; Cossy, J. Org. Lett. 2010, 12, 3693-3695. doi:10.1021/ol101555g

34. Bandini, M.; Sinisi, R.; Umani-Ronchi, A. Chem. Commun. 2008, 4360-4362. doi:10.1039/B807640E

35. Corbett, M. T.; Johnson, J. S. Angew. Chem., Int. Ed. 2014, 53, 255-259. doi:10.1002/anie.201306873

36. Montesinos-Magraner, M.; Cantón, R.; Vila, C.; Blay, G.; Fernández, I.; Muñoz, M. C.; Pedro, J. R. RSC Adv. 2015, 5, 60101-60105. doi:10.1039/C5RA11168D

37. Chauhan, P.; Chimni, S. S. Tetrahedron Lett. 2013, 54, 4613-4616. doi:10.1016/j.tetlet.2013.06.032

38. Li, H.; Wang, Y.; Tang, L.; Deng, L. J. Am. Chem. Soc. 2004, 126, 9906-9907. doi:10.1021/ja047281।

39. Wang, Y.; Liu, X.; Deng, L. J. Am. Chem. Soc. 2006, 128, 3928-3930. doi:10.1021/ja060312n

40. Wu, F.; Hong, R.; Khan, J.; Liu, X.; Deng, L. Angew. Chem., Int. Ed. 2006, 45, 4301-4305. doi:10.1002/anie.200600867

41. Provencher, B. A.; Bartelson, K. J.; Liu, Y.; Foxman, B. M.; Deng, L. Angew. Chem., Int. Ed. 2011, 50, 10565-10569. doi:10.1002/anie.201105536

42. Li, H.; Wang, Y.; Tang, L.; Wu, F.; Liu, X.; Guo, C.; Foxman, B. M.; Deng, L. Angew. Chem., Int. Ed. 2004, 44, 105-108. doi:10.1002/anie.200461923

43. Li, Y.-Z.; Li, F.; Tian, P.; Lin, G.-Q. Eur. J. Org. Chem. 2013, 1558-1565. doi:10.1002/ejoc.201201444

44. Chauhan, P.; Chimni, S. S. Adv. Synth. Catal. 2011, 353, 3203-3212. doi:10.1002/adsc.201100618

45. Deng, Y.-Q.; Zhang, Z.-W.; Feng, Y.-H.; Chan, A. S. C.; Lu, G. Tetrahedron: Asymmetry 2012, 23, 1647-1652. doi:10.1016/j.tetasy.2012.11.008

46. Das, U.; Chen, Y.-R.; Tsai, Y.-L.; Lin, W. Chem. - Eur. J. 2013, 19, 7713-7717. doi:10.1002/chem.201301332

47. Tian, X.; Cassani, C.; Liu, Y.; Moran, A.; Urakawa, A.; Galzerano, P.; Arceo, E.; Melchiorre, P. J. Am. Chem. Soc. 2011, 133, 17934-17941. doi:10.1021/ja207847p

48. Bencivenni, G.; Galzerano, P.; Mazzanti, A.; Bartoli, G.; Melchiorre, P. Proc. Natl. Acad. Sci. U. S. A. 2010, 107, 20442-20447. doi:10.1073/pnas.1001150107

49. Cabanillas, A.; Davies, C. D.; Male, L.; Simpkins, N. S. Chem. Sci. 2015, 6, 1350-1354. doi:10.1039/C4SC03218G

50. Aitken, L. S.; Hammond, L. E.; Sundaram, R.; Shankland, K.; Brown, G. D.; Cobb, A. J. A. Chem. Commun. 2015, 51, 13558-13561. doi:10.1039/C5CC05158D

51. Davis, R. L.; Stiller, J.; Naicker, T.; Jiang, H.; Jørgensen, K. A. Angew. Chem., Int. Ed. 2014, 53, 7406-7426. doi:10.1002/anie.201400241

52. Zhu, Y.; Wang, Q.; Cornwall, R. G.; Shi, Y. Chem. Soc. Rev. 2014, 114, 8199-8256. doi:10.1021/cr500064w

53. Berkessel, A.; Guixà, M.; Schmidt, F.; Neudörfl, J. M.; Lex, J. Chem. - Eur. J. 2007, 13, 4483-4498. doi:10.1002/chem.200600993

54. Arai, S.; Oku, M.; Miura, M.; Shioiri, T. Synlett 1998, 1201-1202. doi:10.1055/s-1998-1932

55. Lykke, L.; Rodríguez-Escrich, C.; Jørgensen, K. A. J. Am. Chem. Soc. 2011, 133, 14932-14935. doi:10.1021/ja2064457

56. Ji, C.-B.; Liu, Y.-L.; Zhao, X.-L.; Guo, Y.-L.; Wang, H.-Y.; Zhou, J. Org. Biomol. Chem. 2012, 10, 1158-1161. doi:10.1039/C2OB06746C

57. Zhou, F.; Zeng, X. P.; Wang, C.; Zhao, X.-L.; Zhou, J. Chem. Commun. 2013, 49, 2022-2024. doi:10.1039/C3CC38819K

58. Wang, Y.; Xiong, T.; Zhao, J.; Meng, Q. Synlett 2014, 25, 2155-2160. doi:10.1055/s-0034-1378548
59. Xiao, X.; Xie, Y.; Su, C.; Liu, M.; Shi, Y. J. Am. Chem. Soc. 2011, 133, 12914-12917. doi:10.1021/ja203138q

60. Wang, F.; Yang, C.; Xue, X.-S.; Li, X.; Cheng, J.-P. Chem. - Eur. J. 2015, 21, 10443-10449. doi:10.1002/chem.201501145

61. Pei, C.-K.; Jiang, Y.; Shi, M. Org. Biomol. Chem. 2012, 10, 4355-4361. doi:10.1039/C2OB25475A

62. Wang, F.; Li, Z.; Wang, J.; Li, X.; Cheng, J.-P. J. Org. Chem. 2015, 80, 5279-5286. doi:10.1021/acs.joc.5b00212

63. Li, C.; Jiang, K.; Chen, Y.-C. Molecules 2015, 20, 13642-13658. doi:10.3390/molecules200813642

64. Gao, T.-P.; Lin, J.-B.; Hu, X.-Q.; Xu, P.-F. Chem. Commun. 2014, 50, 8934-8936. doi:10.1039/C4CC03896G

65. Peng, J.; Ran, G.-Y.; Du, W.; Chen, Y.-C. Org. Lett. 2015, 17, 4490-4493. doi:10.1021/acs.orglett.5b02157

66. Yang, H.-B.; Yuan, Y.-C.; Wei, Y.; Shi, M. Chem. Commun. 2015, 51, 6430-6433. doi:10.1039/C5CC01313E

67. Jaiswal, P. K.; Biswas, S.; Singh, S.; Pathak, B.; Mobin, S. M.; Samanta, S. RSC Adv. 2013, 3, 10644-10649. doi:10.1039/C3RA41409D

68. Singh, S.; Srivastave, A.; Samanta, S. Tetrahedron Lett. 2012, 53, 6087-6090. doi:10.1016/j.tetlet.2012.08.125

69. Bogle, K. M.; Hirst, D. J.; Dixon, D. J. Org. Lett. 2007, 9, 4901-4904. doi:10.1021/ol702277v

70. Bogle, K. M.; Hirst, D. J.; Dixon, D. J. Tetrahedron 2010, 66, 6399-6410. doi:10.1016/j.tet.2010.04.132

71. Bogle, K. M.; Hirst, D. J.; Dixon, D. J. Org. Lett. 2010, 12, 1252-1254. doi:10.1021/ol1000654

\section{License and Terms}

This is an Open Access article under the terms of the Creative Commons Attribution License (http://creativecommons.org/licenses/by/2.0), which permits unrestricted use, distribution, and reproduction in any medium, provided the original work is properly cited.

The license is subject to the Beilstein Journal of Organic Chemistry terms and conditions:

(http://www.beilstein-journals.org/bjoc)

The definitive version of this article is the electronic one which can be found at: doi:10.3762/bjoc. 12.46 